\title{
Anti-Competition Regulation
}

Anne Fleming

Georgetown University Law Center, acf80@law.georgetown.edu

This paper can be downloaded free of charge from:

https://scholarship.law.georgetown.edu/facpub/2223

Business History Review, Vol. 93, Issue 4, 701.

This open-access article is brought to you by the Georgetown Law Library. Posted with permission of the author. Follow this and additional works at: https://scholarship.law.georgetown.edu/facpub

Part of the Banking and Finance Law Commons, and the Transportation Law Commons 


\section{Anne Fleming}

\section{Anti-Competition Regulation}

Looking across the long twentieth century, this article tracks the rise and fall of one form of anti-competition regulation: the certificate of public convenience. Designed to curb "destructive competition" in certain industries, such as transportation and banking, certificate laws prevented firms from entering those industries unless they could convince regulators that they would satisfy an unmet public demand for goods or services. This history highlights how lawmakers used similar techniques in governing infrastructure and finance-two fields that are not often studied together. It also shows that state regulation both prefigured legal change at the federal level and then lagged behind it, suggesting that different dynamics have been in play at each level of governance in devising competition policy over the last century.

Keywords: competition, regulated industries, banking, finance, small-sum lending, transportation, federalism, twentieth century, United States

\footnotetext{
$\mathrm{I}^{\mathrm{n}}$ n 1938, as the United States struggled to emerge from the Great Depression, lawyer Frank Brookes Hubachek stressed the importance of state anti-competition regulation, designed to limit the extent of interfirm rivalry in the marketplace. Hubachek explained that "too intense" competition did not serve the "public interest." 1 This lesson came from experience with the small-sum lending industry, which offered loans of three hundred dollars or less to households in need of quick cash. The business had been regulated since the World War I era, when states began adopting versions of a model lending law, known as the

The author thanks Laura Phillips Sawyer, Herbert Hovenkamp, and an anonymous reviewer for Business History Review for their helpful suggestions that greatly improved this piece.

${ }^{1}$ Frank Brookes Hubachek and Russell Sage Foundation, Annotations on Small Loan Laws: Based on the Sixth Draft of the Uniform Small Loan Law, Small Loan Series (New York, 1938), 54.
}

Business History Review 93 (Winter 2019): 701-724. doi:10.1017/Sooo7680519001223 (C) 2020 The President and Fellows of Harvard College. ISSN 0007-6805; 2044-768X (Web). 
Uniform Small Loan Law, which allowed licensed lenders to charge up to 3.5 percent per month on declining loan balances. In exchange for the ability to charge higher rates than those allowed under most state usury laws, licensed lenders agreed to comply with state licensing requirements and subject themselves to supervision by a state administrator. $^{2}$

The earliest versions of Uniform Law encouraged competition between small-sum lenders by setting minimal barriers to entering the business. Lenders that satisfied the law's licensing requirementsnamely, submitting an application and posting a bond-could operate so long as they abided by the rules specifying permissible loan terms. The Uniform Law drafters sought to encourage "honest capital" to enter the business, on the theory that "competition and the free flow of capital would produce the best results." 3

But, over time, the drafters determined that "competition and natural forces alone would not bring about a distribution of capital in which the supply closely approximated the demand."4 In other words, too much competition encouraged too much lending. Rather than driving down rates of charge, "competitive pressure" had encouraged licensed lenders to engage in "overlending, lending for improvident purposes, excessive and unwise advertising, unjustified and too frequent renewals, offices in towns too small to require them, harsh collection methods, scalping of fees and small overcharges of various kinds." 5 Hubachek observed that competition had fostered these "unsound practices" between the birth of the business and the onset of the Great Depression. ${ }^{6}$

Hence, in 1932, Hubachek helped pioneer new licensing rules that limited the free entry of small-sum lenders into the marketplace. Under these rules, which appeared in the fifth version of the Uniform Law, state small-sum lending regulators could not issue a new license to a lender without first finding that allowing the lender "to engage in business will promote the convenience and advantage of the community

\footnotetext{
${ }^{2}$ The Uniform Law covered only nondepository institutions licensed under the law. It did not cover pawnbrokers, commercial or savings banks, or industrial or Morris Plan banks.

${ }^{3}$ Hubachek and Russell Sage Foundation, Annotations on Small Loan Laws, 53.

${ }^{4}$ Hubachek and Russell Sage Foundation, 53-54.

${ }^{5}$ Frank Brookes Hubachek, "Increased Regulation of Personal Finance" (paper, American Association of Personal Finance Companies 19th Annual Convention, Columbia Libraries, Sept. 1933), 58-59; Hubachek, "The Development of Regulatory Small Loan Laws," Law and Contemporary Problems 8 (1941): 121.

${ }^{6}$ Hubachek, "Increased Regulation," 57.
} 
in which the business of the applicant is to be conducted." 7 New York State had already adopted a similar requirement in $1914 .^{8}$

Hubachek prevailed in convincing some lenders and many lawmakers to support the new version of the Uniform Law. Speaking before the lenders' trade association, Hubachek urged the industry to back the law reform effort rather than wait for lawmakers to impose their own constraints on the business. Failure to address the "evils" of overcompetition, he advised, "is to draw the razor over your own throats-or invite the governments to do so." 9 New Jersey was the first state to adopt the convenience and advantage requirement in 1932, followed by New York later that year. ${ }^{10}$

Much has been written about the history of antitrust and other laws devoted to the preservation and encouragement of interfirm competition. ${ }^{11}$ Historians have likewise explored efforts by private business and administrative agencies to control and manage competition, through measures such as price fixing, from the World War I era through the New Deal. ${ }^{12}$ In addition, they have considered the competitive effects of laws designed to ensure that certain businesses meet minimum safety and quality standards, such as licensing and inspection requirements. ${ }^{13}$ They have also situated these legal developments within the development of economic ideas about markets and their governance. ${ }^{14}$

\footnotetext{
${ }^{7}$ David Jacque Gallert, Walter Stern Hilborn, and Geoffrey May, Small Loan Legislation: A History of the Regulation of the Business of Lending Small Sums (New York, 1932), 234.

${ }^{8}$ New York Laws of 1914, chap. 369.

${ }^{9}$ Hubachek, "Increased Regulation," 59.

${ }^{10}$ Hubachek, "Regulatory Small Loan Laws," 122. By 1969, thirty-three states had this requirement. Robert P. Shay, "Uniform Consumer Credit Code: An Economist's View," Cornell Law Review 54 (1969): 512.

${ }^{11}$ See, for example, Tony Freyer, Regulating Big Business: Antitrust in Great Britain and America, 1880-1990 (Cambridge, U.K., 1992).

${ }^{12}$ See, for example, Laura Phillips Sawyer, American Fair Trade: Proprietary Capitalism, Corporatism, and the "New Competition," 1890-1940 (Cambridge, U.K., 2018); Gerald Berk, Louis D. Brandeis and the Making of Regulated Competition, 1900-1932, 1st ed. (Cambridge, U.K., 2009); and William Boyd, "Just Price, Public Utility, and the Long History of Economic Regulation in America," Yale Journal on Regulation 35 (2018): 721-78. On efforts by railroads to prevent "ruinous" competition even earlier, in the 1870s, see Alfred D. Chandler Jr., The Visible Hand: The Managerial Revolution in American Business (Cambridge, MA, 1977), 133-144.

${ }^{13}$ For example, Gabriel Kolko, The Triumph of Conservatism: A Reinterpretation of American History, 1900-1916 (New York, 1963), 98-108 (meat inspection); Marc T. Law and Sukkoo Kim, "Specialization and Regulation: The Rise of Professionals and the Emergence of Occupational Licensing Regulation," Journal of Economic History 65, no. 3 (2005): 723-56 (occupational licensing); and Richard Sylla, "Federal Policy, Banking Market Structure, and Capital Mobilization in the United States, 1863-1913," Journal of Economic History 29, no. 4 (1969): 657-86 (bank capital requirements).

${ }^{14}$ See, for example, Herbert Hovenkamp, Enterprise and American Law, 1836-1937 (Cambridge, MA, 1991); and Hovenkamp, "United States Competition Policy in Crisis: 1890-1955," Minnesota Law Review 94 (2009): 311-67.
} 
Less attention has been given to explicitly anti-competitive regulations limiting the entry and expansion of competing firms in industries ranging from railroads to small-sum lending across the twentieth century. ${ }^{15}$ This article presents the history of one such regulatory tool: the certificate of public convenience. Unlike licensing rules, which purport to ensure that firms provide a minimum quality of service but may have unadvertised anti-competitive effects, certificate requirements have served no stated purpose other than limiting competition. ${ }^{16}$ The history of certificates therefore offers a direct way to trace prevailing legal practices and ideas about the desirability of competition within certain industries, while disentangling these concerns from those related to ensuring quality standards.

This article tracks the certificate's appearance and later disappearance at the state and federal levels across several industries. It first documents the state-level origins of the certificate, which spread from railroad regulation into other industries, including small-sum lending, between the 1880 s and the New Deal. ${ }^{17}$ It then pivots to the federal level, to show how policymakers followed the example of the states by incorporating certificate requirements into federal law, beginning in the 1920 s. The article also considers the legality of certificate laws, and why they largely survived legal challenges, before examining the movement to rollback certificate laws that first took hold at the federal level in the late 1970s. As the final section shows, the states also reconsidered their anti-competition laws in the 1980s, but certificate requirements lingered for much longer in the states and remain on the books in many jurisdictions today.

This history yields two major insights. First, it shows how lawmakers used similar techniques in regulating competition in infrastructure and in finance-two arenas of regulatory policy that are not often studied together. ${ }^{18}$ In both arenas, lawmakers deployed certificates to ensure

\footnotetext{
${ }^{15}$ Work on particular industries discusses entry restrictions as part of the overall regulatory scheme for that market: e.g., Mark H. Rose, Bruce E. Seely, and Paul F. Barrett, The Best Transportation System in the World: Railroads, Trucks, Airlines, and American Public Policy in the Twentieth Century (Columbus, OH, 2006). On present certificate developments, see Timothy Sandefur, "State Competitor's Veto Laws and the Right to Earn a Living: Some Paths to Federal Reform," Harvard Journal of Law \& Public Policy 38 (2015): 1009-72.

${ }^{16}$ On occupational licensing, see, among others, Morris M. Kleiner, Licensing Occupations: Ensuring Quality Or Restricting Competition? (Kalamazoo, MI, 2006).

${ }^{17}$ Joseph D. Kearney and Thomas W. Merrill, "The Great Transformation of Regulated Industries Law," Columbia Law Review 98 (1998): 1359n161 (noting that certificates for regulated industries began in the states); William K. Jones, "Origins of the Certificate of Public Convenience and Necessity: Developments in the States, 1870-1920," Columbia Law Review 79 (1979): 426-516.

${ }^{18}$ Morgan Ricks, "Money as Infrastructure," Columbia Business Law Review 2018, no. 3 (2018): 767 (noting the "kinship" between bank regulation and "infrastructure" regulation that is "seldom recognized in the regulatory literature").
} 
that the total supply of goods and services produced in a community did not exceed the public demand, thereby discouraging unsound competitive practices that could lead to business failures. Second, it also shows that state regulation prefigured legal change at the federal level and then lagged behind it, suggesting that different forces have been at work at each level of governance in devising competition policy over the last century. ${ }^{19}$

\section{The Beginning of "Public Convenience and Necessity" in the States}

By the time New Jersey adopted a "convenience and advantage requirement" for licensing small-sum lenders in 1932, existing state laws already subjected other businesses to similar entry restrictions. The move toward anti-competition regulation began with the railroads in 1882, when Massachusetts amended its law to mandate that the state administrators not issue a license for a new railroad or expansion of an existing road unless they found that "public convenience and necessity" required its construction. ${ }^{20}$ The state adopted this provision at the urging of its Board of Railroad Commissioners, a state administrative agency that reviewed applications for new roads. "The history of railroad enterprises shows that needless and useless roads have been constructed from spite, from a desire to control or annoy other railroad companies, and still more frequently from a spirit of mad speculation," the board observed in $1881 .{ }^{21}$ It later noted that, without the board's review of new railroad construction plans, unnecessary railroads could be built and then fail before the builders could pay off investors, creditors, and the landowners whose property was seized for the road through eminent domain. ${ }^{22}$

Thereafter, New York railroad administrators sought a similar rule for their state, noting that "excessive" construction of roads led to ratecutting wars between rival railroads, insufficient revenue for roads to engage in basic maintenance and safety precautions, and ultimately "leases, consolidation, or 'pools,' designed to secure from the people ... an ample return upon the entire capital thus in part unnecessarily expended." 23 In the administrators' view, state control of railroad rates imposed a "corresponding obligation" on the state "to protect existing

\footnotetext{
${ }^{19}$ On policymaking at the state level see, for example, Alexander Hertel-Fernandez, "Who Passes Business's 'Model Bills'? Policy Capacity and Corporate Influence in U.S. State Politics," Perspectives on Politics 12, no. 3 (2014): 582-602.

${ }^{20}$ Jones, "Origins," 435-36.

${ }^{21}$ Jones, 435 (quoting 12 Mass. Bd. of R.R. Comm'rs Ann. Rep. 57 [1881]).

${ }^{22}$ Jones, 436 (quoting 15 Mass. Bd. of R.R. Comm'rs Ann. Rep. 30 [1884]).

${ }^{23}$ Jones, 438 (citing 1 N.Y. Bd. of R.R. Comm'rs Ann. Rep. 64 [1884]).
} 
railroads from useless and disastrous competition by unnecessary new [roads]."24 Although some competition could yield "public benefits," it "ought not to be permitted to become ruinous, destructive, and demoralizing." 25 The New York legislature granted the administrators' request for this review power in $1892 .{ }^{26}$

Thereafter, state legislators and industrial reformers embraced the use of entry restrictions in utility regulation more broadly. The National Civic Federation, a coalition of labor and business reformers that supported large-scale industrial combinations, drafted a model bill in 1914 for public-utility regulation that included a "public convenience and necessity" licensing requirement. ${ }^{27}$ In support of its approach, the federation observed that administrative regulation was "inconsistent" with unfettered competition. ${ }^{28}$ State court judges likewise concluded that entry restrictions were justified as a means to control the cost of providing services to the public. "It is for the benefit of the public that the highest efficiency be obtained from a public utility and that it serve the public at the lowest cost," wrote the Utah Supreme Court. It concluded that "such an end cannot be reached if the community is served by duplicate plants." 29 Academics similarly understood the certificate requirement as a means to "to prevent unnecessary duplication of utility properties through the introduction of competition where the public welfare demands the recognition of monopoly."30

Although some public-utility providers initially opposed state regulatory efforts, as in New York State, the industry generally came to support state commission regulation as an alternative to the uncertainty of local and municipal control. ${ }^{31}$ The movement for state legislation crested between 1905 and 1920, when thirty-two states limited the entry and expansion of public-utility providers-such as telephone, electric, and gas suppliers-based on whether state administrators found that a new licensee would serve the "public convenience and necessity." 32

\footnotetext{
${ }^{24}$ Jones, 438.

25 “The Railroad Commissioners' Report," New York Times, 14 Jan. 1885 (quoting 1885 New York Commissioners report).

${ }^{26}$ Jones, "Origins," 439, 445-46.

${ }^{27}$ Jones, 452.

${ }^{28}$ Jones, 452-53.

${ }^{29}$ Idaho Power \& Light Co. v. Blomquist, 141 P. 1083, 1090 (1914). See also Weld v. Gas \& Elec. Light Comm'rs, 84 N.E. 101, 102-3 (1908).

${ }^{30}$ I. Leo Sharfman, "Commission Regulation of Public Utilities: A Survey of Legislation," Annals of the American Academy of Political and Social Science 53 (1914): 11.

${ }^{31}$ Gregg A. Jarrell, "The Demand for State Regulation of the Electric Utility Industry," Journal of Law \& Economics 21, no. 2 (1978): 293-94; Jones, "Origins," 453. On New York State, see Robert F. Wesser, Charles Evans Hughes: Politics and Reform in New York, 1905-1910 (Ithaca, 1967), 158-59.

${ }^{32}$ Jones, "Origins," 454-55; Ford Poulton Hall, "Certificates of Convenience and Necessity," Michigan Law Review 28 (1929): 121n78.
} 
States imposed similar restrictions on bus lines operators and other "common carriers" beginning in 1913.33 By 1947, forty-seven out of forty-eight states required some common carriers and public utilities to obtain a certificate of convenience and necessity. 34

Although not considered to be public utilities, financial institutions also became subject to state "convenience and advantage" restrictions on their creation and expansion beginning in the early twentieth century, after a spate of bank failures. New York State began restricting the opening of new banks and existing bank branches in 1908, following the failure of several banks during the panic of 1907.35 The change was recommended by a commission of bankers, who were appointed by the governor after the panic to propose legal reforms to avert future bank failures, and was endorsed by both the state banking superintendent and the governor. ${ }^{36}$ The legislature amended the state banking law accordingly. Thereafter, the state banking administrator could not approve a new bank charter without first finding that it would promote the "public convenience and advantage." 37

Other states imitated New York. Massachusetts imposed a similar restriction for savings banks later that same year. ${ }^{8}$ Shortly thereafter, in 1909, California likewise adopted a "public convenience and advantage" branch-approval requirement based on New York's model.39 In 1911, Kansas similarly granted its banking board the power to deny a bank charter application if "public necessity" did not support the bank's creation. Later that same year, the Kansas board explained the purpose of public-necessity review, in a decision denying a bank charter. "The establishment of additional banks in a town where the business is not such as to demand or justify the establishment of such banks has a tendency to weaken and make unsafe all of the banks in said town," the board noted. "The division of the business is such that it is difficult for the banks to obtain the amount of deposits necessary in order to earn a return sufficient to pay expenses and a dividend on the capital, and creates a temptation to pay high and unsafe rates of

\footnotetext{
${ }^{33}$ Jones, "Origins," 485.

${ }^{34}$ Ford Poulton Hall, State Control of Business through Certificates of Convenience and Necessity (Bloomington, IN, 1947), 21-25.

${ }^{35}$ Shirley Donald Southworth, Branch Banking in the United States (New York, 1928), 131; Edwin Stokes, "Public Convenience and Advantage in Applications for New Banks and Branches," Banking Law Journal 74 (Dec. 1957): 922-23. The state already restricted the entry of new savings banks and trust companies. Stokes, $923 n 7$.

${ }^{36}$ Wesser, Charles Evans Hughes, 186-87; "The Bank Commission Report," New York Times, 30 Dec. 1907, 6; "State Banking Committee Report Suggests Many Changes," Wall Street Journal, 18 Dec. 1907, 8.

${ }^{37}$ Southworth, Branch Banking, 131; New York Laws of 1908, chap. 125

${ }^{38}$ Stokes, "Public Convenience," $923 n 7$.

${ }^{39}$ Southworth, Branch Banking, 36-38.
} 
interest on the deposits, and further makes it difficult for banks to loan their money to safe borrowers, and creates a tendency to lend money to unsafe borrowers, the result of all of which is to cause unsafe banking." 40 To encourage safe banking, the state charged the board with preventing new banks from entering communities that already had sufficient banking facilities.

More states followed suit a couple of decades later, in reaction to the bank failures of the Great Depression. ${ }^{41}$ As economist Robert P. Shay later observed, legislative reformers in the 1930 s commonly blamed "competitive excesses in the 1920's as a cause for difficulties experienced by financial institutions during the Great Depression." 42 All states eventually imposed some version of a convenience and advantage requirement for new bank charters, as well as for bank branches in states that allowed branching. 43 States also incorporated this requirement into their licensing rules for small-sum lenders beginning in 1932, at the urging of attorney Frank Brookes Hubachek. 44

But most certificate laws did not tell state administrators how to determine what would "promote the convenience and advantage of the community," leaving bureaucrats to develop their own standards. 45 For example, the New Jersey state small loans administrator, James M. Sullivan, developed the "Sullivan formula" to assess new small-sum lending license applications. ${ }^{46}$ Sullivan first used U.S. census data to calculate the total number of potential borrower households in the state and then looked to state-level borrowing statistics to determine how many potential borrowers actually used small loans. ${ }^{47}$ He then determined whether any unmet need for credit existed in the community where the licensee planned to locate, based on an assessment of the need for small loans within the community and a survey of the existing lenders located there. The administrator would refuse to grant a new license in any area where he found that existing loan offices already met the

\footnotetext{
${ }^{40}$ Schaake v. Dolley, 118 P. 8o, 83-84 (Kan. 1911).

${ }^{41}$ John W. Transelle, "The Efficiency of Liberalizing Branch Banking in Indiana," Indiana Law Review 13 (1980): 800-1.

${ }^{42}$ Shay, "Uniform Consumer Credit Code," 512.

${ }^{43}$ Stokes, "Public Convenience," 921; "Bank Charter, Branching, Holding Company and Merger Laws: Competition Frustrated Notes and Comments," Yale Law Journal 71, no. 3 (1962): 510-11.

${ }^{44}$ Hubachek, "Regulatory Small Loan Laws," 122.

${ }^{45}$ This was true at the federal level as well, e.g., I.C.C. v. Parker, 326 U.S. 6o, 65 (1945).

${ }^{46}$ Household Finance Corp. v. Gaffney, 90 A.2d 85, 87 (N.J. Super. Ct. App. Div. 1952); James A. Sullivan, "A Statement on the Convenience and Advantage Clause: The Method of Application Used and the Policy Applied in New Jersey," n.d., folder 190: Consumer Credit Studies, 1944-1951, box 24, Russell Sage Foundation records, Rockefeller Archive Center, Sleepy Hollow, NY.

${ }^{47}$ Sullivan, "Statement on Convenience and Advantage."
} 
community's need for credit. ${ }^{48}$ State banking regulators applied similarly detailed calculations to determine whether to grant new branch or bank applications. 49

As these administrative procedures show, certificate restrictions were different in kind from licensing rules and other regulations not expressly designed to cap the number of firms operating in a given region. "Under the typical licensing statute any number of applicants may receive authorizations if each of them satisfies applicable licensing criteria," one scholar observed. "The test is essentially qualitative." But certificate requirements included a "quantitative dimension." They resulted in the "exclusion of otherwise qualified applicants from a market because, in the judgment of the regulatory commission, the addition of new or expanded services would have no beneficial consequences or, in a more extreme case, would actually have harmful consequences." ${ }^{\circ}$ The law did not distinguish between big and small businesses, nor seek to shelter small enterprises from firms with large market power. Indeed, it favored the growth of existing firms into bigger businesses, by empowering administrators to block the entry of a new firm if an existing company already adequately served the market or had the potential to do so..$^{1}$

Across industries, courts and state administrators cited a common purpose for these rules: to benefit the public by eliminating "wasteful competition." 52 For infrastructure, the harmful consequences of competition included "wasteful duplication" of facilities, "ruinous competition" between providers, "cream skimming" of the most profitable customers by new operators that diminished the quality of service given to lessprofitable customers by existing providers, discouragement of future investment in the regulated industry, and various negative "externalities" such as environmental harms.53 For "motor carriers," for example, entry restrictions prevented the public streets from being overcrowded and worn down by "over-use." They also curbed "cut-throat competition" between motor carriers that might discourage these

\footnotetext{
${ }^{48}$ See, for instance, Family Finance Corp. v. Gough, 76 A.2d 82 (N.J. Super. Ct. App. Div. 1950).

${ }^{49}$ Stokes, "Public Convenience," 929.

${ }^{50}$ Jones, "Origins," 427.

${ }^{51}$ See, for example, Egyptian Transp. Sys. v. Louisville \& N.R. Co., 152 N.E. 510, 513 (Ill. 1926) (setting aside state commerce commission's grant of certificate to a new bus line to provide service on the grounds that the two existing railroads that served the same route must be given "the first right to furnish" the proposed service); and Sohngen v. Pub. Utilities Comm'n of Ohio, 154 N.E. 734, 735 (Ohio 1926) (affirming state public utility commission's grant of a certificate to an existing bus line to extend its service and simultaneous denial of certificate to new entrants to serve the same route).

${ }^{52}$ Hall, State Control of Business, 10.

${ }^{53}$ Jones, "Origins," 501; Hall, "Certificates of Convenience and Necessity," 108-9.
} 
carriers from serving less-profitable routes and cause some to go out of business, thereby thwarting the goal of serving the public's "need for efficient permanent service." 54 Likewise, for financial services, competition could lead to overproduction and excessive risk-taking that might, in the case of deposit-taking institutions, imperil the overall safety of the banking system or, in the case of small-sum lenders, subject consumers to predatory practices.

Economic thinking further bolstered the case for certificates. In 1894, economist Richard T. Ely deemed some industries to be natural monopolies: namely, "railways, telegraphs, telephones, canals, irrigation works, harbors, gasworks, street-car lines, and the like." 55 Natural monopolies generally supplied a necessary good, occupied valuable land, and could increase the available supply of goods and services without increasing marginal costs. ${ }^{6}$ In these businesses, Ely declared, there could be no competition and "all appearances which resemble competition are simply temporary and illusory" stages preceding combination. 57

Economists did not claim, however, that banks or licensed lenders were natural monopolies. Rather, their arguments for limiting competition in these markets rested solely on concerns about consumer welfare. Economist Clyde Olin Fisher observed that if the goal of small-sum lending regulation was to protect the "worthy borrower," then "it is difficult to see wherein it becomes necessary to grant a license to every group which wishes to invade the small loan field in the hope of picking up a few dollars"-especially when "duplication makes necessary a higher interest charge." ${ }^{8}$ Fisher also drew parallels between the consumer lending and transportation industries in explaining why limits on competition served the public interest in obtaining lower-cost services. Competition among consumer lenders would not "lower rates," just as "the duplication of railroad lines where one road can handle all the traffic" would not yield "reduced railroad rates." He explained that "the duplication of companies under a 'laissez-faire' policy must cause higher overhead and hence a higher interest charge."59

\footnotetext{
${ }^{54}$ David E. Lilienthal and Irwin S. Rosenbaum, "Motor Carrier Regulation by Certificates of Necessity and Convenience," Yale Law Journal 36, no. 2 (1926): 164-66.

${ }^{55}$ Richard T. Ely, "Natural Monopolies and the Workingman: A Programme of Social Reform," North American Review 158, no. 448 (1894): 294.

${ }^{56}$ Richard T. Ely, "The Telegraph Monopoly," North American Review 149, no. 392 (1889): 45 .

${ }^{57}$ Ely, "Natural Monopolies," 294.

${ }^{58}$ Clyde Olin Fisher, "The Small Loans Problem: Connecticut Experience," American Economic Review 19, no. 2 (1929): 191.

${ }^{59}$ Clyde Olin Fisher, "Reply on Small Loans Problem," American Economic Review 19, no. 4 (1929): 645 .
} 
Of course, certificate laws also benefited incumbent businesses by blunting the threat of competition by new entrants to the industry. But interest group pressure alone cannot account for the spread of these laws at the state level. Indeed, among small-sum lenders, the value of such laws to existing operators was not self-evident in the 1930 . Hubachek had to make the case for law reform to the industry and his pitch focused on how certificate laws could forestall more onerous state intervention in the marketplace, not on the benefits to incumbents. Interest group influence alone does not explain the spread of certificates. Rather, the popularity of certificate laws also reflected then-prevailing concerns about the harm that competition could inflict on the public. Thus, economic thinking and the interests of industry incumbents both pushed in the same direction in the early twentieth centurytoward constraints on competition in the markets for financial services and infrastructure.

\section{The Migration to the Federal Level}

Certificate requirements migrated into federal laws governing public utilities and financial institutions in the 1930s. It is not surprising that these ideas first took root in the states, given the delayed emergence of the federal administrative state relative to its state and local counterparts. To be sure, a federal administrative state existed prior to the New Deal. Much of the regulatory action remained at the state level, however, until the Great Depression catalyzed the expansion of a national bureaucracy to manage an economy where commerce increasingly moved across state and local borders. The federal adoption of certificates began in 1920, when Congress required railroads to obtain a certificate of convenience and necessity in order to construct new lines or expand existing lines. The provision received no congressional debate, perhaps because lawmakers were already familiar with state certificate laws and saw little reason not to import the same standard into federal railroad regulation. ${ }^{60}$

The spread of entry restrictions then accelerated during the New Deal, when economic thinking on competition aligned closely with the self-interest of industry. By 1932, amid the Great Depression, a rising chorus of businessmen called for the federal government to intervene against the destructive forces of "excessive competition." As historian

\footnotetext{
${ }^{60}$ Transportation Act of 1920, Pub. L. 66-152, 41 Stat. 456; James C. Roberton, “Administrative Regulation by Conditions in Certificates of Public Convenience and Necessity Recent Development," Stanford Law Review 21, no. 1 (1968): 192. Roberton notes that Congress ignored the certificate provision and instead debated other aspects of this legislation when deliberating on the bill (p. 192).
} 
Ellis Hawley recounts, trade association leaders, economists, and former government officials likewise praised proposals for regulating production, prices, and entry. ${ }^{61}$ One proposal by the head of a "management engineering" firm sought to require the issuance of certificates of convenience and advantage to those entering an industry already "possessed of excess capacity," to prevent Americans from continuing to be "crucified on the cross of competition." 62

The National Industrial Recovery Act represented the most intense, albeit short-lived, federal effort to control competition. Enacted in 1933, the law required the creation of codes of "fair competition" that would govern maximum working hours, minimum wages, and other conditions of employment in each industry. Although the law did not mention certificates of convenience, several industries included a certificate requirement in their codes of fair competition. ${ }^{63}$ The National Recovery Administration was disbanded in short order, however, after the Supreme Court declared the code system unconstitutional in $1935 .{ }^{64}$

But Congress explicitly imposed certificate requirements for utility providers as part of several New Deal legislative measures, which followed the model of the 1920 federal railroad certificate regime. The Communications Act of 1934 required communications carriers, such as telephone companies, to receive a "certificate of public convenience and necessity" from the Federal Communications Commission (FCC) before constructing new lines or extending existing lines. ${ }^{65}$ Likewise, the federal Motor Carrier Act of 1935 required common carriers engaged in interstate transportation of people or goods to receive a certificate of public convenience and necessity from the Interstate Commerce Commission. ${ }^{66}$ In 1938, Congress vested the authority to grant certificates of convenience for domestic airline carriers in the Civil Aeronautics Authority, later renamed the Civil Aeronautics Board (CAB). ${ }^{67}$ It also applied similar rules to interstate natural gas providers. ${ }^{68}$

As with the 1920 railroad certificate requirement, Congress did not debate these provisions, which one commentator described as "neglected fragments of much larger legislative undertakings." 69 The Interstate Commerce Commission (ICC) did, however, explain why it endorsed

\footnotetext{
${ }^{61}$ Ellis W. Hawley, The New Deal and the Problem of Monopoly (Princeton, 1966), 41.

${ }^{62}$ Hawley, 40-41. Charles R. Stevenson, The Way Out (New York, 1932), 26-27.

${ }^{63}$ Hall, State Control of Business, 9.

${ }^{64}$ A.L.A. Schechter Poultry Corp. v. United States, 295 U.S. 495 (1935).

${ }^{65}$ Communications Act of 1934, Pub. L. 73-416, 48 Stat. 1064.

${ }^{66}$ John J. George, "Federal Motor Carrier Act of 1935," Cornell Law Quarterly 21, no. 2 (1936): $235-36$.

${ }^{67}$ Civil Aeronautics Act of 1938, Pub. L. No. 75-706, 52 Stat. 973.

${ }^{68}$ Natural Gas Act of 1938, Pub. L. No. 75-688, 52 Stat. 821.

${ }^{69}$ Roberton, "Administrative Regulation," 192-93.
} 
entry restrictions and included a certificate provision in an early draft of what became the Motor Carrier Act of 1935. In 1928, as part of an investigation into the regulation of motor carriers, the ICC observed that a majority of states required operators of common-carrier motor vehicles to obtain certificates, which protected "the public interest" by "excluding unnecessary and wasteful competition" and preventing "duplication and unnecessary service where existing facilities are sufficient." 70 Six years later, the ICC noted that "free-for-all competition has never worked successfully" and warned that "unless competition is brought under greater restraint, it can bring only wide-spread losses to shippers, to communities and sections of the country, to investors in rail, water, and motor facilities, and to the public generally."71 It predicted that a certificate requirement would help bring order to the motor carrier industry, in part by increasing the average size of each carrier operation and decreasing the total number of operators in existence. ${ }^{72}$ Thus, rather than try to prevent industry consolidation, the ICC advocated for certificates as a means to encourage it.

Financial regulation at the federal level followed a similar course during the Great Depression. ${ }^{73}$ In 1933, Congress imposed limits on banks' payments of interest to depositors in order to lessen "the pressures of rate competition for deposit funds," which pushed banks to "reach for riskier, higher-yielding loans and investments." 74 Congress then amended the Federal Reserve Act in 1935 to require the Comptroller of the Currency to consider the "convenience and needs of the community to be served" before approving a new national bank charter. ${ }^{75}$ It also created the same screening requirement for admission of new state banks to the Federal Reserve System and for coverage of nonmember state banks by the Federal Deposit Insurance Corporation (FDIC). ${ }^{76}$ In explaining the need to limit entry of new banks, the FDIC chairman observed that "many localities" generated a sufficient volume of deposits to support "only one or two banks" and that the entry of additional banks

\footnotetext{
${ }^{70}$ Motor Bus and Motor Truck Operation, 140 I.C.C. 685, 746 (1928); George M. Chandler, "Convenience and Necessity: Motor Carrier Licensing by the Interstate Commerce Commission," Ohio State Law Journal, no. 3 (1967): 380.

${ }^{71}$ Regulation of Transportation Agencies, Second Report of the Federal Coordinator of Transportation, S. Doc. No. 152, 73d Cong., 2d Sess. 23, 24 (1934).

${ }^{72}$ Regulation of Transportation Agencies, 28, 30.

${ }^{73}$ Daniel R. Fischel, Andrew M. Rosenfield, and Robert S. Stillman, "The Regulation of Banks and Bank Holding Companies," Virginia Law Review 73 (1987): 302.

${ }^{74}$ Shay, "Uniform Consumer Credit Code," 513.

${ }^{75}$ Stokes, "Public Convenience," 926; Banking Act of 1935, Pub. L. 74-305, 49 Stat. 684; David A. Alhadeff, "A Reconsideration of Restrictions on Bank Entry," Quarterly Journal of Economics 76, no. 2 (1962): 249.

${ }^{76}$ Sam Peltzman, “Entry in Commercial Banking," Journal of Law \& Economics 8 (1965): 12. See also Bank Holding Company Act of 1956, Pub. L. 84-511, 70 Stat. 133.
} 
would lead to "speculative and destructive practices."77 The FDIC supported entry restrictions as a means to avoid a "return to the overbanked condition of 1920" and the "growth of excessive banking facilities" that had led to bank failures. ${ }^{8}$

Some small-sum lenders smiled knowingly while witnessing the beginnings of these shifts at the federal level. They proudly observed that their business had anticipated the "social viewpoint of the New Deal" and incorporated it into their governing law. In 1933, one lender encouraged "the business man" to "turn to personal finance for a clarifying illustration of how the principles of the New Deal can work in practice."79 Before an assembly of small-sum lenders, he noted that "personal finance" had already "anticipated the general aims and methods of planned economy," while also urging his colleagues to "go still further along the path indicated" by measures such as the National Industrial Recovery Act. ${ }^{80}$ And, for the business to really align itself "with the spirit of the times," he counseled, it should "embrace more wholeheartedly the idea of the certificate of convenience and advantage" that the Uniform Law had introduced in $1932 .{ }^{81}$

\section{Legal Authority to Curtail Competition}

Just as state-level certificate laws anticipated federal regulatory developments, legal challenges to state-level certificate laws likewise preceded their expansion at the federal level. Between 1905 and 1937, courts struck down a variety of economic regulations for infringing on individual liberty of contract, which was protected by the due process clause of the Fourteenth Amendment. The period came to be known as the Lochner era, after a U.S. Supreme Court decision invalidating a state law that limited bakers' working hours on due process grounds. ${ }^{82}$ Courts regularly reviewed legislation to determine if it represented a proper exercise of state police powers or unconstitutional overreaching. The U.S. Supreme Court had occasion to review the legality of state certificate requirements in 1932, just as state and federal legislators were considering applying such rules to additional industries in response to the economic collapse of the Depression.

\footnotetext{
${ }^{77}$ Banking Act of 1935, Hearing Before a Subcommittee of the Senate Committee on Banking and Currency, 74th Cong., 1st sess., 32 (1935) (statement of Leo T. Crowley, chairman of the board, FDIC).

${ }^{78}$ Banking Act of 1935, Hearing at 31.

${ }^{79}$ M. R. Neifeld, "Economic Aspects of Personal Finance" (paper, American Association of Personal Finance Companies 19th Annual Convention, Columbia Libraries, Sept. 1933), 34.

${ }^{80}$ Neifeld, 34 .

${ }^{81}$ Neifeld, 34 .

${ }^{82}$ Lochner v. New York, 198 U.S. 45 (1905).
} 
The question of whether certificate restrictions ran afoul of the due process clause first came before the Court in 1932, in the case of New State Ice Co. v. Liebmann, which concerned the constitutionality of an Oklahoma certificate requirement for businesses engaged in the sale, manufacture, or distribution of ice. ${ }^{83}$ Under the law, the state administrator could not issue an operating license "except upon proof of the necessity for a supply of ice at the place" where the licensee "sought to establish the business" and could deny an application if the existing licensees provided sufficient ice facilities "to meet the public needs" of the community. ${ }^{84}$ As the Court explained, the purpose of the law was "not to encourage competition, but to prevent it; not to regulate the business, but to preclude persons from engaging in it." 85

The resulting decision in New State Ice shows how the nature of the industry determined the extent of permissible state control under the jurisprudence of the Lochner era. A majority of the Court struck down the Oklahoma ice law based on the "character" of the ice business. Justice Sutherland, for the majority, explained that the Oklahoma law might be permissible if applied to a business of a certain character, such as a natural monopoly or "an enterprise in its nature dependent upon the grant of public privileges." But the law was not permissible when applied to businesses engaged in "ordinary manufacture and production." 86

This approach tracked the Court's due process decisions from the late nineteenth century through the early 1930s. Under these cases, a business could fall within one of three categories: public utilities, those "affected with the public interest," and private enterprises. Public utilities were subject to the greatest state control, while private enterprises stood at the other end of the spectrum. As early twentieth-century legal scholars explained, "public service corporations" or "public utilities" were outliers, encompassing "those few businesses where the conditions are monopolistic" and the business held itself out as offering an essential or necessary service to the general public. ${ }^{87} \mathrm{~A}$ business

\footnotetext{
${ }^{83}$ New State Ice Co. v. Liebmann, 285 U.S. 262 (1932). See also Buck v. Kuykendall, 267 U.S. 307 (1925) (Commerce Clause challenge); and Frost v. Corp. Commission of Okla., 278 U.S. 515 (1929) (equal protection challenge).

${ }^{84} \mathrm{New}$ State Ice, 285 U.S. at 272.

${ }^{85}$ New State Ice, 285 U.S. at 279.

${ }^{86}$ New State Ice, 285 U.S. at 279.

${ }^{87}$ Bruce Wyman, The Special Law Governing Public Service Corporations, and All Others Engaged in Public Employment (New York, 1911), viii; Thomas P. Hardman, "Public Utilities: I. The Quest for a Concept," West Virginia Law Quarterly \& The Bar 37 (1930): 251 (summarizing Wyman's definition). But, for a list of all of the businesses that fell within the public utility category, see William J. Novak, "The Public Utility Idea and the Origins of Modern Business Regulation," in Corporations and American Democracy, ed. Naomi R. Lamoreaux and William J. Novak (Cambridge, MA, 2017), 139-76.
} 
"affected with the public interest" rested in the middle zone; it could be subject to greater state oversight than a private enterprise but did not have the same universal service obligations or regulatory burdens as common carriers and other public utilities. ${ }^{88}$ (Small-sum lenders, for example, accepted that their business was "affected with the public interest" but vigorously rejected any suggestion that they were utilities.) ${ }^{89}$ Finally, there were run-of-the-mill commercial businesses, such as ice making, which were not subject to the heightened forms of economic regulation that might be applied to enterprises in the other two categories. Although the Supreme Court struck down the certificate law in New State Ice, the decision also affirmed the constitutionality of certificate laws when applied to regulate public utilities or businesses "affected with the public interest." And courts generally upheld the constitutionality of certificate restrictions so long as they were applied to such businesses. ${ }^{90}$

The constitutionality of certificate laws then became even easier to establish after the Supreme Court revised its approach to due process claims in 1934. That year, in Nebbia $v$. New York, the Court abandoned the effort to define which businesses were "affected with the public interest." 91 And shortly thereafter, in 1937, the Court announced it would no longer subject economic regulations to any form of heightened scrutiny, regardless of the nature of the industry. Constitutional due process required only that an economic regulation be "reasonable in relation to its subject" and "adopted in the interests of the community," the Court proclaimed. ${ }^{92}$ Legislators merely had to show that a rational basis existed for the rules that they adopted.93

Thus, by the 1950s, when certificate rules for small-sum lenders came before state courts, judges easily dismissed due process challenges to their constitutionality. ${ }^{4}$ In one New Jersey case, the objecting applicants argued that the convenience and advantage requirement of the

\footnotetext{
${ }^{88}$ Charles Wolff Packing Co. v. Court of Indus. Relations of State of Kansas, 262 U.S. 522, 543 (1923). On the effort to define "affected with the public interest," see Samuel R. Olken, "The Decline of Legal Classicism and the Evolution of New Deal Constitutionalism," Notre Dame Law Review 89 (2014): 2057-60; Malcolm Rutherford, "The Judicial Control of Business: Walton Hamilton, Antitrust, and Chicago," Seattle University Law Review 34 (2011): 1391; and Herbert Hovenkamp, "The Political Economy of Substantive Due Process," Stanford Law Review 40 (1988): 442.

${ }^{89}$ Anne Fleming, City of Debtors: A Century of Fringe Finance (Cambridge, MA, 2018), 73.

${ }^{90}$ Hall, "Certificates of Convenience and Necessity," 111.

${ }^{91}$ Nebbia v. New York, 291 U.S. 502, 536 (1934).

${ }^{92}$ W. Coast Hotel Co. v. Parrish, 300 U.S. 379, 391 (1937).

${ }^{93}$ United States v. Carolene Products Co., 304 U.S. 144, 152 (1938).

${ }^{94}$ Gough, 76 A.2d at 87; Family Finance Corp. v. Gaffney, 95 A.2d 407, 409 (1953). See also Equitable Loan Soc. v. Bell, 14 A.2d 316 (Pa. 1940); and Kelleher v. Minshull, 119 P.2d 302 (Wash. 1941).
} 
state small loan law violated the "fundamental common right to engage in a lawful pursuit," protected by the Fourteenth Amendment. ${ }^{95}$ The New Jersey judiciary rejected this claim. It found that the small-sum lending industry was "clothed with a public interest" and was therefore "subject to regulation." 96 Moreover, the court concluded, the entry restriction had "a direct and immediate connection with the public interest." 97

In the 1950s, the U.S. Supreme Court even went so far as to reprimand the FCC for neglecting to follow congressional intent to curtail competition in certain industries. The Court addressed the parameters of federal competition policy in the case of FCC $v$. RCA (1953), which arose after the FCC granted an international radiotelegraph service's application to extend its service into a competitor's market. The FCC cited a "national policy in favor of competition" in its decision approving the application. But Justice Frankfurter, writing for the majority, found that the FCC had misinterpreted its mandate from Congress. "That there is a national policy favoring competition cannot be maintained today without careful qualification," Justice Frankfurter wrote..$^{98}$ In railroads, for example, federal "policy has shifted from one of prohibiting restraints on competition to one of providing relief from the rigors of competition," he explained. In telecommunications, as in railroads, federal lawmakers did not trust in "competition as the regulating mechanism." Nor was competition desirable when "considerations severely limit the number of separate enterprises that can efficiently, or conveniently, exist."99 The FCC, therefore, could not grant a certificate of convenience and necessity based on the presumed, but unproven, benefits of increasing competition. ${ }^{100}$ The Court remanded the case.

\section{The Decline of Anti-Competition Regulation at the Federal Level}

Although "public convenience and necessity" entry restrictions gradually disappeared at the federal level in the 1970s and 1980s, legal challenges in the courts did not hasten their demise. Rather, their disappearance tracked changing ideas about the proper role of the state and competition in the marketplace, which ushered in a larger legal paradigm shift. ${ }^{101}$ Although many forces converged to encourage this

${ }^{95}$ Gaffney, 95 A.2d at 409-10. See also Gough, 76 A.2d at 87.

${ }^{96}$ Gough, 76 A.2d at 87.

${ }^{97}$ Gaffney, 95 A.2d at 411. See also Kelleher, 119 P.2d at 309; Motors Acceptance Corp. v. McLain, 47 N.W.2d 919, 922 (1951).

${ }^{8}$ F.C.C. v. RCA Communications Inc., 346 U.S. 86, 91 (1953).

${ }^{99}$ RCA, 346 U.S. at 92.

${ }^{100} \mathrm{RCA}, 346$ U.S. at 97.

${ }^{101}$ Kearney and Merrill, “Great Transformation,” 1328. 
transformation, ideological change combined with interest-group activism accounts for its pervasiveness across industries. ${ }^{102}$ Calls for change accelerated in the 1970s, as both liberal and conservative thinkers decried the existing paradigm of regulation in industries such as aviation and trucking. ${ }^{103}$ Furthermore, the oil crisis, rising inflation, and a middecade recession all deepened public anxiety about economic issues and created a window for change. ${ }^{104}$

Economists, most notably Alfred Kahn and George Stigler, provided the intellectual underpinnings for the movement to roll back anticompetition laws, while Senator Edward Kennedy worked within Congress to make the case for regulatory reform. ${ }^{105}$ First, during the Ford administration, Kennedy held hearings on the need for airline regulation, which spawned an internal review by the Civil Aeronautics Board (CAB). A couple of years later, president Jimmy Carter then appointed Kahn as $\mathrm{CAB}$ chair; Kahn proceeded to experiment with loosening entry restrictions. ${ }^{106}$

In advocating for reform, Kahn drew on decades of economic research that critiqued regulatory restrictions of competition. Well before Kahn's appointment, in the late 1930s, economists had revised their thinking about "ruinous competition," which came to be understood as a problem limited to markets with undifferentiated products. ${ }^{107}$ "Passenger air transportation," Kahn explained in 1970, "does not have the economic attributes of an industry prone to destructive competition." Moreover, he argued, "freer competition" would provide "enormous potential benefits" to the consuming public. ${ }^{108}$ This analysis resonated with the ascendant Chicago School of economics and conservative critics of the regulatory state, as well as with consumer advocacy groups. The existing airlines and their employees were the major opponents of deregulation. ${ }^{109}$

\footnotetext{
${ }^{102}$ Kearney and Merrill, 1329.

${ }^{103}$ Kearney and Merrill, 1325 .

${ }^{104}$ Thomas K. McCraw, Prophets of Regulation: Charles Francis Adams, Louis D. Brandeis, James M. Landis, Alfred E. Kahn (Cambridge, MA, 1984), 259.

${ }^{105}$ Alfred E. Kahn, The Economics of Regulation: Principles and Institutions, 2 vols. (New York, 1970); George J. Stigler, “The Theory of Economic Regulation," Bell Journal of Economics and Management Science 2, no. 1 (1971): 3-21; McCraw, Prophets of Regulation; Richard H. K. Vietor, "Contrived Competition: Airline Regulation and Deregulation, 19251988,” Business History Review 64, no. 1 (1990): 81.

${ }^{106}$ Vietor, "Contrived Competition," 82-83.

${ }^{107}$ Hovenkamp, "United States Competition Policy," 320, 326-30, 341-43.

${ }^{108}$ Kahn, Economics of Regulation, 2:220.

${ }^{109}$ McCraw, Prophets of Regulation, 263, 269. On the politics of deregulation more generally, see Martha Derthick and Paul J. Quirk, The Politics of Deregulation (Washington, DC, 1985); and Shane Hamilton, "The Populist Appeal of Deregulation: Independent Truckers and the Politics of Free Enterprise, 1935-1980," Enterprise \& Society 10, no. 1 (2009): 137-77.
} 
After Kahn's experiments at the $\mathrm{CAB}$, Congress began removing certificate of convenience requirements. It started with the passage of the Airline Deregulation Act of $1978 .{ }^{110}$ Prior to Kahn's tenure, the CAB and other federal agencies in charge of issuing certificates had curtailed the entry of new providers in regulated markets. In the airline industry, for example, the $\mathrm{CAB}$ denied all seventy-nine applications for new domestic airlines that were filed between 1950 and $1974 .{ }^{111}$ But with passage of the 1978 act, domestic airline applicants no longer had to prove convenience and necessity; they were presumed. CAB could deny an application only if it found that the presumption was rebutted. ${ }^{112}$

The process continued into the 1980 s and 1990s. Congress lowered regulatory barriers to entry for interstate truckers in 1980, before eliminating "convenience and necessity" review entirely in $1995 .{ }^{113}$ Also in 1995, Congress lowered barriers to entry for railroads and granted the ICC authority to exempt railroads from existing regulatory requirements, including certificates. ${ }^{114}$ For telecommunications, the certificate requirement remained on the books a while longer, but in 1996, Congress exempted line extensions and cable television providers entirely from the certificate requirement and authorized the FCC to "forbear" from enforcing it for other providers. ${ }^{115}$ Three years later, pursuant to this authority, the FCC adopted a rule that conferred blanket authorization for the construction of new domestic communications lines. ${ }^{116}$

In banking, the demise of entry restrictions came about largely through administrative action, with some legislative encouragement. Through the 1960s, federal regulators had frequently cited "insufficient need" as the basis for denials of new bank charters. ${ }^{117}$ The Federal Reserve had likewise refused to allow mergers involving bank holding companies on this basis, policing against the dangers of overbanking or excessive competition. But the tide began to shift when Congress amended the Bank Merger Act in 1966, which made clear the importance of preserving competition within the banking industry and allowed anticompetitive mergers to proceed only upon proof of a countervailing

\footnotetext{
${ }^{110}$ Airline Deregulation Act of 1978, Pub. L. 95-504, 92 Stat. 1705.

${ }^{111}$ Kearney and Merrill, "Great Transformation," $1350 n 117$.

${ }^{112}$ Congress also adopted the Natural Gas Policy Act in 1978. Pub. L. 95-621, 92 Stat 3350.

${ }^{113}$ Motor Carrier Act of 1980, Pub. L. 96-296, 94 Stat. 793; ICC Termination Act of 1995,

Pub. L. No. 104-88, 109 Stat. 803.

${ }^{114}$ ICC Termination Act of 1995, Pub. L. No. 104-88, 109 Stat. 803.

${ }^{115}$ Joseph D. Kearney, "Will the FCC Go the Way of the ICC?," University of Colorado Law Review 71 (2000): 1171n84; Section 214 Deregulated Entry Requirements and Streamlined Exit Requirements for Domestic Telecommunications Common Carriers, 64 Fed. Reg. 39938-01 (23 July 1999).

${ }^{116}$ Section 214 Deregulated Entry Requirements, 64 Fed. Reg. 39938-01.

${ }^{117}$ Fischel, Rosenfield, and Stillman, "Regulation of Banks," 331n85.
} 
benefit to meeting the "needs" of the community. ${ }^{118}$ The act's express language, affirming the value of competition, suggested that a reduction in competition was not in itself a countervailing public benefit.

The following decade, Congress further muddled the meaning of the "convenience and needs" of the community with its passage of the 1977 Community Reinvestment Act (CRA), which imposed obligations on banks to lend in their communities. ${ }^{119}$ The Federal Reserve then began to equate "convenience and needs" with fulfillment of a bank's fairlending obligations under the CRA. ${ }^{120}$ And the Office of the Comptroller of the Currency also announced that it would no longer seek to "protect existing competitors from the competition a new bank will provide" as part of its charter application review. ${ }^{121}$ In the 1980 s, the Justice Department likewise adopted a more permissive approach to its review of bank mergers, lessening the chance that a merger would be deemed anticompetitive so as to require official consideration of a countervailing benefit to the "convenience and needs" of the community. ${ }^{122}$ The "convenience and needs of the community" requirement remained on the books for some limited purposes, but the language proved sufficiently vague to allow regulators enormous discretion in its interpretation..$^{123}$

\section{State Anti-Competition Laws Linger}

Like the federal government, the states also began removing certificate requirements in the last decades of the twentieth century. However, they proceeded in a halting, piecemeal fashion that left numerous entry restrictions in place. In the late 1970s, when the federal rollback began, many states still required certificates for businesses to enter most socalled public-service enterprises: those engaged in the provision of

\footnotetext{
${ }^{118}$ Act of Feb. 21, 1966, Pub. L. No. 89-356, 80 Stat. 7. See also Act of July 1, 1966, Pub. L. No. 89-485, 80 Stat. 236 (similar standard for banking holding company mergers).

${ }^{119}$ Warren L. Dennis, "The Community Reinvestment Act of 1977: Defining Convenience and Needs of the Community," Banking Law Journal 95 (1978): 693-717.

${ }^{120}$ Mehrsa Baradaran, "Banking and the Social Contract," Notre Dame Law Review 89 (2014): 1339-40.

${ }^{121}$ Rules, Policies and Procedures for Corporate Activities; Charter Policy, 45 Fed. Reg. 68605 (15 Oct. 1980). In 1991, Congress officially removed the requirement. Ricks, "Money as Infrastructure," 820.

${ }^{122}$ Arthur E. Wilmarth Jr., "The Transformation of the U.S. Financial Services Industry, 1975-2000: Competition, Consolidation, and Increased Risks," Illinois Law Review 2002, no. 2 (2002): 250. On recent mergers, see Mitria Wilson, "Protecting the Public's Interests: A Consumer-Focused Reassessment of the Standard for Bank Mergers and Acquisitions," Banking Law Journal 130 (2013): 350-78. See also Depository Institutions Deregulation and Monetary Control Act of 1980, Pub. L. No. 96-221, 94 Stat. 132 (lifting restrictions on interest paid on demand deposits).

${ }^{123} 12$ U.S.C. 1816 (FDIC); 12 U.S.C. 1842 (Bank Holding Companies); Michael P. Malloy, Banking Law and Regulation, 2nd ed. (2014, 2019 supp.), § 2.02.
} 
transportation (e.g., railroads, street railroads, motor carriers), communications (e.g., telephone, telegraph, cable television), and gas, electric, and water supply. ${ }^{124}$ They also limited the ability of small-sum lenders and banks to form and grow by requiring proof that a new office would serve the convenience and needs of the community. ${ }^{125}$ States further expanded their certificate requirements in the 1960 s and 1970 s to limit the construction of new healthcare facilities based on "community need," partially in response to federal urging. ${ }^{126}$

The lowering and removal of barriers to entry at the state level was most sweeping in the banking arena, perhaps because banks dissatisfied with their home state chartering rules could easily avoid them by pursuing a federal charter or a charter in a different state. ${ }^{127}$ This competition among jurisdictions created pressure on states to make their chartering rules less onerous in order to encourage financial institutions to locate within their borders. ${ }^{128}$ States generally kept the "convenience and needs" standards for new bank charters and banks, but many reinterpreted the meaning of this standard to lower the barrier to entry. ${ }^{129}$ In addition, barriers to interstate bank branching gradually eroded over the 1980 s. $^{130}$ Congress then adopted the Riegle-Neal Act in 1994, which removed the remaining federal barriers to interstate branching and encouraged states to allow out-of-state banks to open branches in their jurisdictions. ${ }^{131}$

On the other hand, for industries that were unlikely to move across state lines or seek a federal charter, many states retained certificate requirements. As economists and legal scholars have repeatedly observed, these rules benefit entrenched service providers, who have

${ }^{124}$ Jones, "Origins," 427-28.

125 "Bank Charter," 514. For branching standards as of 1985, see Cynthia Young Reisz, "The Future of Shared Automatic Teller Networks in the Wake of Marine Midland Bank: A Call for Federal Legislation," Vanderbilt Law Review 38 (1985): 1627. New York eliminated convenience and advantage from its branching rules in 1981. New York Laws of 1981, c. 411, § 1; New York Banking Law s. 24, 29 (2018).

${ }^{126}$ Lauretta Higgins Wolfson, "State Regulation of Health Facility Planning: The Economic Theory and Political Realities of Certificates of Need," DePaul Journal of Health Care Law 4, no. 2 (2001): 266.

${ }^{127}$ Frank H. Easterbrook, "Antitrust and the Economics of Federalism," Journal of Law \& Economics 26 (1983): 34-35.

${ }^{128}$ On competition between the states leading to rollback of regulations on financial institutions, see Fleming, City of Debtors, 229-31.

${ }^{129}$ See Dep’t of Fin. Institutions v. Wayne Bank \& Tr. Co., 385 N.E.2d 482, 484 (Ind. Ct. App. 1978); and First Nat. Bank of Worland v. Fin. Institutions Bd., 616 P.2d 787, 798 (Wyo. 1980).

${ }^{130}$ Christian A. Johnson and Tara Rice, "Assessing a Decade of Interstate Bank Branching," Washington and Lee Law Review 65 (2008): 84-85.

${ }^{131}$ Riegle-Neal Interstate Banking and Branching Efficiency Act of 1994, Pub. L. No. 103328, 108 Stat. 2338. States could opt out of Riegle-Neal, but fewer than a dozen did. Johnson and Rice, "Assessing a Decade," 87. 
an interest in lobbying to retain protections from more intense competition. ${ }^{132}$ Recently, a couple of states removed their certificate restrictions for intrastate household movers, in response to litigation by libertarian public-interest groups attacking state licensing rules and certificate requirements on constitutional grounds. ${ }^{133}$ But, under a rational-basis standard of review, these requirements generally have withstood judicial scrutiny. ${ }^{134}$ The majority of states likewise still have some "certificate of need" requirement for new healthcare-facility construction. ${ }^{135}$

The proposed Uniform Consumer Credit Code ( $\left.\mathrm{U}_{3} \mathrm{C}\right)$, a model state law that would have significantly increased competition in the small-sum lending arena, similarly failed to receive widespread adoption in the states. The U3C, first promulgated in 1968 and revised in 1974, would have eliminated "convenience and advantage" licensing requirements. ${ }^{136}$ But, as one commentator noted, the "vested interests" in the industry did not like this aspect of the law. ${ }^{137}$ Most states accordingly failed to adopt the law and instead retained their existing small loan laws. New Mexico, for example, still includes a convenience and advantage requirement in its small-sum lending regulations. ${ }^{138}$

\section{Conclusion}

This history, tracing the flow and ebb of rules requiring certificates of public convenience and necessity to enter certain industries, yields two insights for historians of business and scholars of economic policy. First, by following a single regulatory technique across several industries and through time, it shows the "kinship" between past approaches to

\footnotetext{
${ }^{132}$ For example, Stigler, "Theory of Economic Regulation."

${ }^{133}$ Sandefur, "State Competitor's Veto Laws," 1045-46; Timothy Sandefur, "A Public Convenience and Necessity and Other Conspiracies against Trade: A Case Study from the Missouri Moving Industry," George Mason University Civil Rights Law Journal 24 (2014): 185; Bruner v. Zawacki, 997 F. Supp. 2d 691 (E.D. Ky. 2014); Munie v. Koster, 4:10CVo1096AGF (E.D. Mo.) (dismissed 12 July 2012 as moot).

${ }^{134}$ Sandefur, "Public Convenience and Necessity," 99-100. But see Bruner, 997 F. Supp. 2d at 691. See also Parker v. Brown, 317 U.S. 341 (1943) (shielding firms acting pursuant to a state anti-competition law from federal antitrust enforcement).

135 "Certificate of Need State Laws," National Conference of State Legislatures (NCSL) website, accessed 23 Jan. 2019, http://www.ncsl.org/research/health/con-certificate-ofneed-state-laws.aspx.

${ }^{136}$ See also National Commission on Consumer Finance, Consumer Credit in the United States (Washington, DC, 1972), 138.

${ }^{137}$ William L. Sartoris, "The Convenience and Advantage Clause in Small-Loan Legislation: Pro and Con," Business Lawyer 27, no. 1 (1971): 349. For a defense of the convenience and advantage requirement, see J. Barry Harper, "The Uniform Consumer Credit Code and Freedom of Entry," Business Lawyer 24, no. 1 (1968): 227-35.

${ }^{138}$ Only eleven states ultimately adopted some version of the U3C. N.M. Stat. Ann. § 58-155 (West 2018).
} 
regulation of infrastructure and financial institutions. ${ }^{139}$ Although trucking companies and small-sum lenders may seem to contemporary observers to have little in common, lawmakers once understood the two industries as suffering from the same tendencies toward ruinous competition, which necessitated similar regulatory restraints. In both contexts, lawmakers aimed to curb competition not to rein in big business but to discourage unsound business practices that could harm the public or cause companies to collapse. Further comparative study of the regulation of finance and infrastructure over time may yield additional evidence of policy echoes between the two.

Second, by looking at the history of capitalism within federalism, this history illustrates the importance of incorporating states into stories about economic regulation in the twentieth century. ${ }^{140}$ At minimum, it offers a more nuanced periodization of shifts in American competition policymaking. When viewed from the federal level, this story of anti-competition regulation follows a familiar pattern: the tide of regulation flowed in with the New Deal and receded during the Carter and Reagan administrations. But the story looks different when it includes developments in the states. From this vantage point, the narrative begins earlier, in the late nineteenth century, when states began experimenting with regulatory techniques that Congress later copied into federal law. ${ }^{141}$ Also, the end point of the story is later and less well defined: many states have retained their anti-competition rules for some industries even as the tide quickly turned against legal restraints on competition at the federal level in the late 1970 s and 1980 s.

Beyond illustrating the strange and syncopated rhythms of policymaking in a federalist system, this periodization also suggests different political dynamics at play at each level of government. The states and federal government, beginning at different moments, both eventually imposed certificate requirements on a variety of industries, backed by then-prevalent economic ideas about competition and, sometimes, by the support of entrenched firms. Shortly thereafter, however, the economic consensus shifted to favor eliminating such restrictions in most industries. But it was only at the federal level that these new ideas, coupled with the support of other interest groups, led to the widespread rollback of certificate laws beginning in the 1970s. At the state level,

${ }^{139}$ Ricks, "Money as Infrastructure," 767.

${ }^{140}$ On the importance of studying the role of the states, see William R. Childs, "State Regulators and Pragmatic Federalism in the United States, 1889-1945," Business History Review 75, no. 4 (2001): 701-38; and Harry N. Scheiber, "State Law and 'Industrial Policy' in American Development, 1790-1987," California Law Review 75, no. 1 (1987): 415-44.

${ }^{141}$ On this dynamic in consumer credit regulation in the 1960s and 1970s, see Fleming, City of Debtors, 217-18. 
rollback occurred when the regulated firms could easily move across state lines, spurring regulatory competition between the states to lower legal barriers to entry. But state certificate rules have persisted in other corners of the economy. This suggests that the power of entrenched business interests to retain anti-competitive regulation varies significantly across political contexts; it is heightened when governance occurs at the state and local level and in the absence of regulatory competition between jurisdictions.

ANNE FLEMING is professor of law at Georgetown University. She is the author of City of Debtors: A Century of Fringe Finance (2018), which explores the growth and regulation of small-sum lending institutions in the United States over the twentieth century. City of Debtors received the 2019 Ralph Gomory Prize from the Business History Conference. 